\title{
Mid-septal accessory pathway in a young professional athlete: when and how to ablate?
}

\author{
loan-Alexandru Minciuna², Mihai Puiu', Gelu Simu², Gabriel Cismaru',2, Radu Rosu',2, Dumtru Zdrenghea ${ }^{1,2}$,
} Dana Pop ${ }^{1,2}$

\begin{abstract}
Wolf-Parkinson-White (WPW) syndrome is responsible for $1 \%$ of all deaths in athletes. Considering the increased risk of sudden cardiac death (SCD) in athletes compared to general population, a comprehensive risk stratification is crucial. Both American and European guidelines recommend electrophysiology (EP) study for risk assessment and catheter ablation as the first-line treatment in athletes with WPW syndrome. Radiofrequency (RF) catheter ablation is the routine treatment for most accessory pathways (AP). However, cryo-energy ablation is recommended for APs located close to the atrioventricular node, in particular mid-septal and superoparaseptal, because of the increased risk of complete atrioventricular block with RF ablation. Depending on the European or American guidelines, athletes should be granted clearance for competitive sports I month after the procedure if free of symptoms and without pre-excitation recurrence on ECG.
\end{abstract}

Keywords: Mid-septal, accessory pathway, athlete, electrophysiology study, ablation.

Rezumat: Sindromul Wolf-Parkinson-White (WPW) este responsabil pentru 1\% din totalul deceselor la sportivii de performanță. Având în vedere riscul crescut de moarte subită cardiacă a acestora comparativ cu populația generală, o evaluare comprehensivă a riscului este crucială. Atât ghidul european cât și cel american recomandă efectuarea unui studiu electrofiziologic pentru evaluarea riscului de moarte subită și a ablației cu cateter la sportivii de performanță cu sindrom WPW. Ablația cu radiofrecvență este tratamentul de elecție pentru majoritatea căilor accesorii. Totuși, crioablația este recomandată pentru căile accesorii localizate în apropierea nodului atrioventricular, în particular cele mid-septale și superoparaseptale, din cauza riscului crescut de bloc atrioventricular complet prin utilizarea ablației cu radiofrecvență. În funcție de ghidul european sau american, sportivilor de performanță le este recomadată reînceperea activității sportive la o lună după ablație dacă nu au mai prezentat simptome și nu a reapărut preexcitația pe ECG.

Cuvinte cheie: Mid-septal, cale accesorie, atlet, studiu electrofiziologic, ablație.

\section{INTRODUCTION}

Wolf-Parkinson-White (WPW) syndrome accounts for aproximately $1 \%$ of all deaths in athletes ${ }^{1,2}$. The first step for these patient's management should be the sudden cardiac death (SCD) risk stratification, being known that APs with low refractory periods may lead to life-threatening arrhythmias ${ }^{3}$. The American guidelines recommend that in asymptomatic athletes with pre-excitation engaged in moderate- to high-level competitive sports, invasive risk stratification of the
AP through electrophysiology (EP) study is advisable, but not mandatory. On the other hand, the European Society of Cardiology recommends that all athletes with ventricular pre-excitation, regardless of symptoms, should perform an EP study in order to determine the most appropriate therapeutic option ${ }^{1-6}$. Catheter ablation of the AP is recommended for all athletes with regular, acute-onset, symptomatic supraventricular tachycardia or with APs presenting high-risk EP characteristics, in particular refractory period $<250 \mathrm{~ms}$,

\footnotetext{
' „Iuliu Hatieganu” University of Medicine and Pharmacy, Cluj-Napoca, Romania

${ }^{2}$ Departament of Cardiology-Rehabilitation, Clinical Rehabilitation Hospital, Cluj-Napoca, Romania
}

\footnotetext{
$\checkmark$ Contact address:

loan-Alexandru Minciuna, ,Iuliu Hatieganu” University of Medicine and Pharmacy, Cluj-Napoca, Romania.

E-mail: iaminciuna@gmail.com
} 
before restoring competitive activity ${ }^{1,3}$. Furthermore, for APs with low-risk EP characteristics, competitive sports may be allowed without performing ablation, especially for APs located very close to the atrioventricular node, such as mid-septal APs'. Nevertheless, in these patients, cryo-balloon ablation may be a safe treatment option, having a lower risk of atrioventricular block compared to radiofrequency (RF) catheter ablation, but a higher recurrence rate ${ }^{1,2}$. Finally, depending on the European or American guidelines, athletes should be granted clearance for competitive sports one month after the procedure ${ }^{6}$.

\section{CASE PRESENTATION}

A 22-year-old Caucasian professional boxer male with history of WPW syndrome was admitted to our cardiology department for fast, regular palpitations. He had no ECG documented tachycardia and reported the absence of symptoms until 4 weeks ago. From that moment, the patient presented 5 episodes of palpitations with sharp debut and end, lasting for 2-3 minutes, one of the episodes during boxing practice. At presentation ECG revealed sinus rhythm, pre-excitation and delta wave - positive in DII and aVF and negative in leads DIII and VI with QRS transition in V2-3 (Figure I). Echocardiography showed normal cardiac function.

Considering the patient's WPW syndrome history and typical tachycardia symptoms, an EP study was performed in order to assess the risk of life-threatening arrhythmias. At the beginning of the procedure surface ECG showed the same pre-excitation pattern
(Figure 2A), suggestive for a mid-septal AP, which was confirmed by the fusion between atrial and ventricular electrocardiograms in this region (Figure 2B). During atrial and ventricular programmed electrical stimulation, the AP showed both antegrade and retrograde conduction, the refractory period of the AP being measured as $250 \mathrm{~ms}$ (Figure 2C). Taking into account the borderline high-risk characteristics of the AP and in accordance with the European Society of Cardiology recommendations, we decided to perform catheter ablation of the AP. At catheter manipulation in the mid-septal, para-hisian region, pre-excitation disappeared mechanically, but was followed by consequent self-limited $2^{\text {nd }}$ degree 2:I AV block (Figure 2D). Low-energy (5-I0W) RF ablation shots were applied where the ventricular electrocardiogram on the ablation catheter was earliest compared to surface delta waves, in order not to harm the normal atrioventricular conduction system. Pre-excitation disappeared several times during the RF shots, but its recurrence was noticed each time after a couple of minutes of waiting (Figure 2E $+2 \mathrm{~F}$ ). Moreover, $\mathrm{AH}$ interval prolongation was observed during RF shots. As a result of atrioventricular conduction disturbances, we decided to stop the procedure and reschedule the patient for cryo-ablation.

One week after the first procedure, a second EP study was performed, aiming to ablate the AP using cryo-energy. At the beginning of the procedure the patient showed the same pre-excitation pattern on surface ECG as on admission. Programmed electri-

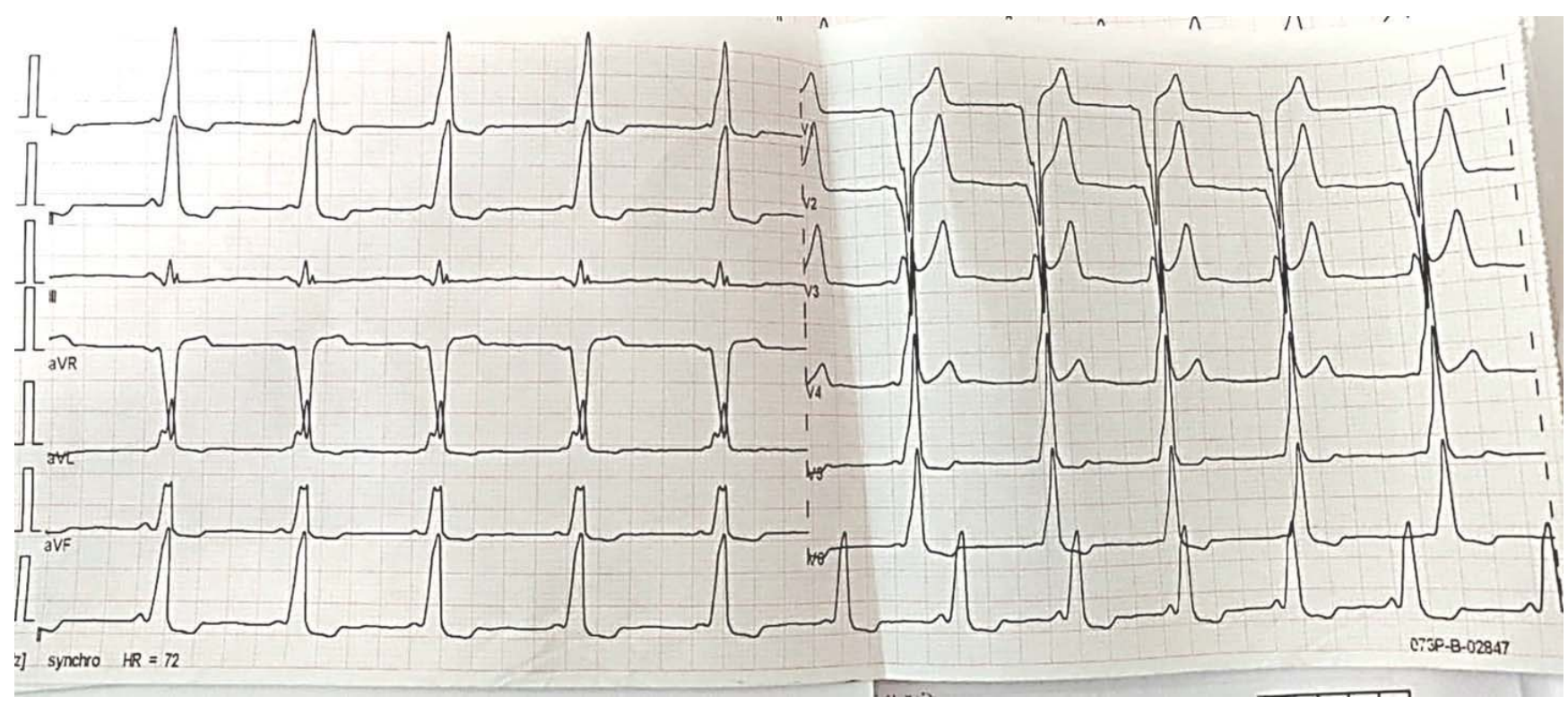

Figure I. ECG at admission: sinus rhythm, 72 bpm, pre-excitation and delta wave - positive in DII and aVF, negative in DIII,VI with transition in V2-V3. 

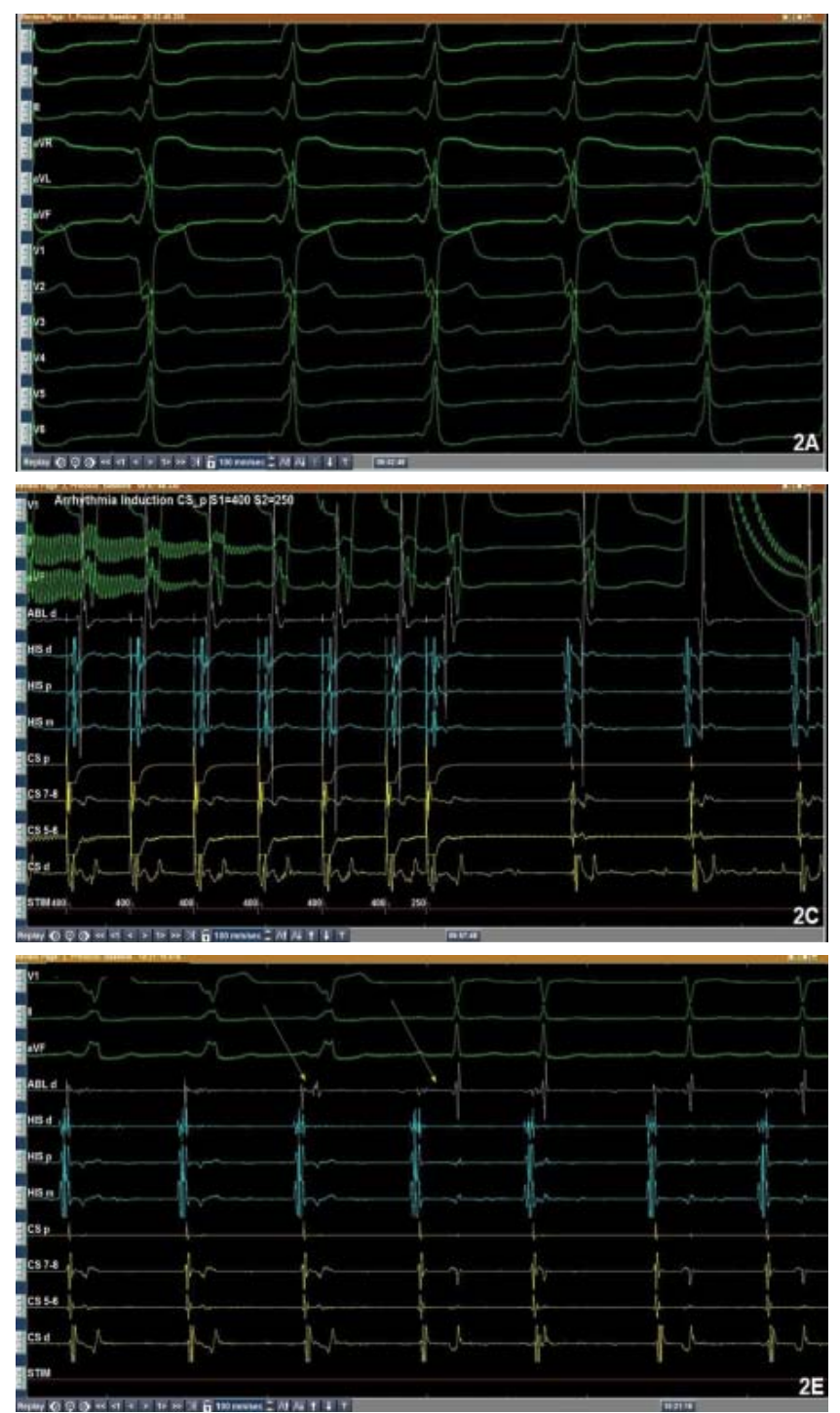
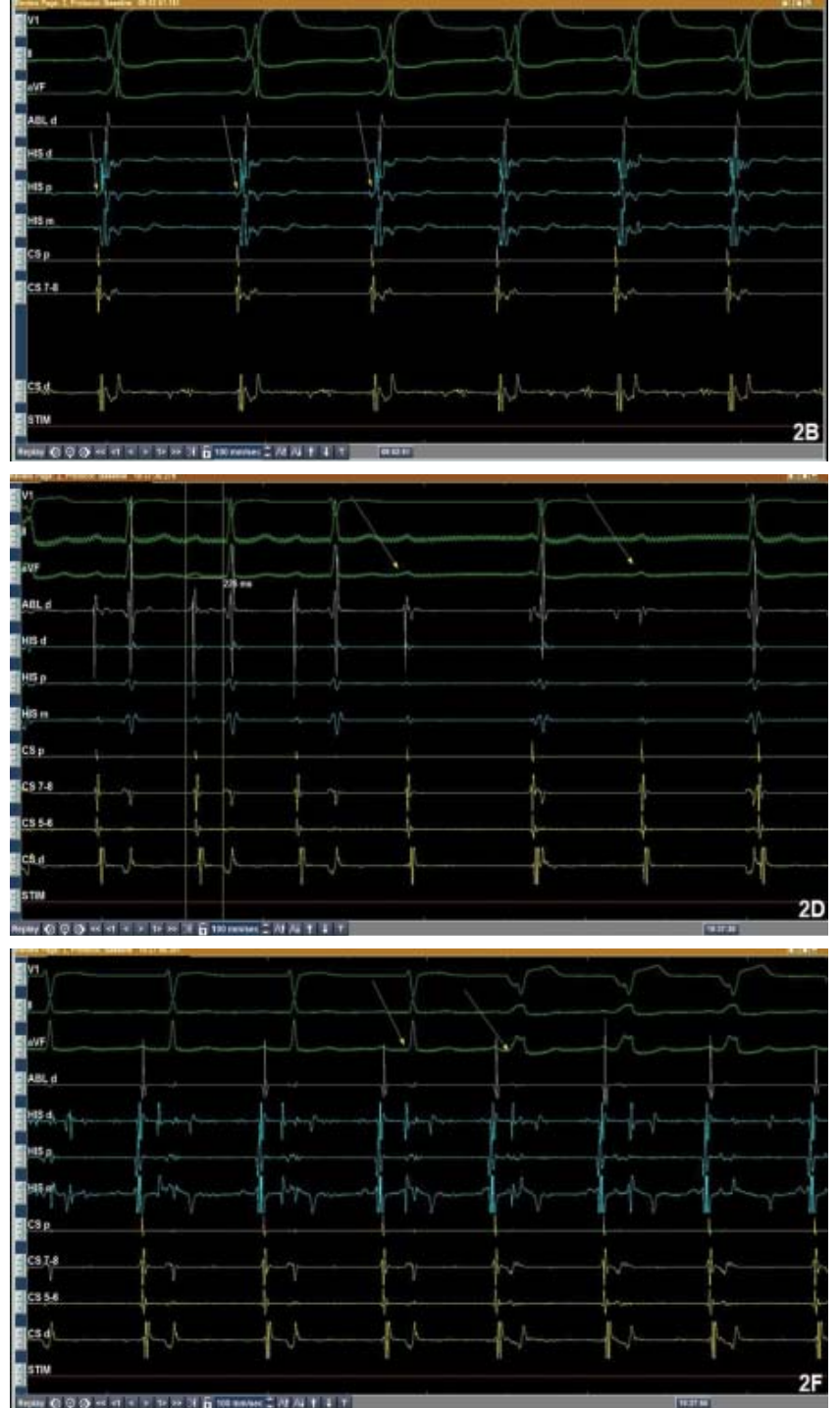

Figure 2. EP study and RF ablation.A. Surface ECG at the beginning of the procedure showing pre-excitation and delta waves suggestive of a mid-septal AP; B. Fusion between atrial and ventricular electrograms on His catheter; C. Refractory period of the AP=250 ms; D. 2nd degree 2:I AV block during catheter manipulation in mid-septal area; E. Disappearance of fusion and pre-excitation during RF shots - note that first yellow arrow shows fusion on ablation catheter corresponding to pre-excitation on surface ECG while the second yellow arrow highlights the loss of both fusion and pre-excitation; F. Recurrence of fusion and pre-excitation. $E P=$ electrophysiology; $R F=$ radiofrequency' $A P=$ accessory pathway.

cal stimulation was performed showing the same AP pathway characteristics as in first procedure, so we decided to begin cryo-ablation. A first cryo-energy shot was performed in the para-hisian region, with the disappearance of pre-excitation but with consequent $2^{\text {nd }}$ degree 2:I AV block, both reversible after discontinuing the shot (Fig. 3A). We advanced the catheter a little further in the para-hisian area and performed a second cryo-energy shot for 240 s, with the disappearance of pre-excitation and no AV conduction disturbances (Figure 3B). At the end of this second shot, right bundle branch block occurrence was noticed, which persisted throughout the entire procedure. After 30 minutes waiting time, there was no pre-excitation recurrence. We decided to stop the procedure.

The patient was discharged 3 days after the procedure with surface ECG showing sinus rhythm, right bundle branch block and the absence of pre-excitation. At check-up, 4 weeks and 3 months after discharge, the patient displayed the same surface ECG pattern as on discharge, reporting the absence of palpitations or other symptoms. As a result, he was granted clearance to resume competitive sports. 

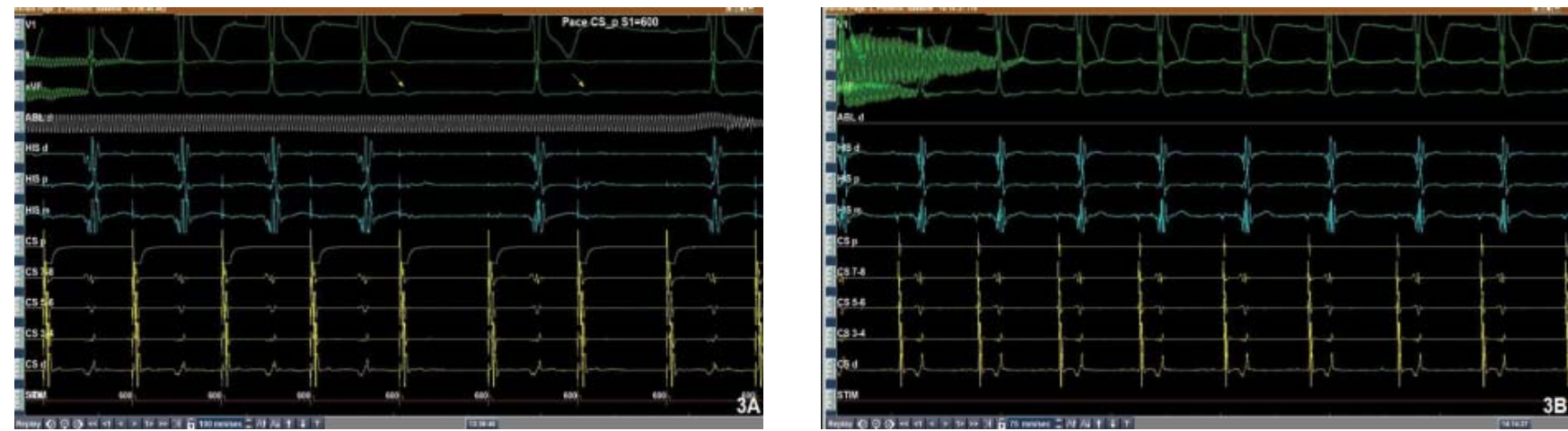

Figure 3. Cryo-ablation. A. $2^{\text {nd }}$ degree $2: I$ AV block during first cryo-energy shot - note the interferences on the white ablation catheter (ABL d) showing cryo-energy application was on-going; B. No pre-excitation or fusion at the end of the cryo-ablation procedure.

\section{DISCUSSIONS}

The borderline refractory period of the AP in a patient with history of supraventricular tachycardia confirms the high-risk criteria for SCD. Furthermore, considering that the risk of SCD is increased in athletes, it is important to find the best therapeutic option in the shortest amount of time ${ }^{7}$.

Regarding the best approach for athletes with WPW syndrome, the recommendation of the American and European cardiology societies differ. The former recommends invasive management only after comprehensive risk stratification, in asymptomatic athletes involved in moderate to high-intensity competitive sports, while the latter recommends invasive management for all athletes with WPW syndrome, regardless of sport ${ }^{2-4,6}$. Nevertheless, both societies recommend catheter ablation as the treatment of choice for athletes with regular, acute-onset, symptomatic supraventricular tachycardia ${ }^{3}$. In our case, the EP team recommended to perform EP study and catheter ablation as soon as possible, taking into account that the patient presented multiple tachycardia episodes, of which one during training.

Careful localization of APs on surface ECG is an important factor in planning the ablation procedure as it can provide guidance in choosing the best ablation method'. Surface ECG in our patient suggested a midseptal AP, which was subsequently confirmed during the EP study.

RF catheter ablation represents the routine treatment for most $\mathrm{APs}^{8,9}$. However, cryo-thermal ablation for septal APs is established as a safe and successful technique, significantly reducing the risk of AV block ${ }^{1,8,9}$. Practically, the immediate discontinuation of cryo- energy at any temperature guarantees the reversibility of AV node conduction disturbances I. No permanent AV block has been reported yet ${ }^{1,9}$. With respect to success rates, cryo-ablation has lower success rates compared to RF ablation for APs, with recurrence rates in up to $25 \%$ of cases ${ }^{1,2,8-10}$. However, many of the patients with septal APs treated through cryo-ablation had previously been subjected to RF ablation, which was aborted due to AV conduction disturbances ${ }^{8}$. As a consequence, previous RF ablation in these patients is being considered a risk factor for AP recurrence. Therefore, considering that many of the RF ablations of septal APs had to be aborted, the overall success rate might shift into cryo-ablation's favor. In the end, for septal APs, cryo-ablation may become the elective treatment and not just an alternative to RF ablation ${ }^{1,8,9}$. In our case, the AV block occurrence during RF ablation in a young athlete made the decision to stop de procedure easy. The patient underwent cryo-ablation without any persistent $\mathrm{AV}$ conduction disturbances.

Several studies found that one frequent complication of cryo-ablation of septal APs is the appearance of bundle branch block. Depending on the localization of the AP near the septum, APs located more anteriorly are linked to right bundle branch block and those located more posteriorly to left bundle branch block ${ }^{11,12}$. Moreover, right bundle branch block has also been reported in patients with mid-septal APs treated by cryo-ablation'.

Finally, both guidelines, the American and the European one, recommend 4 weeks of resumption of competitive sports after the procedure. Both require the absence of symptoms and of pre-excitation on surface ECG at follow-up ${ }^{5,6}$. 


\section{CONCLUSIONS}

Competitive athletes with WPW syndrome have an increased SCD risk compared to general population. In order to assess the SCD risk, EP study should be performed and catheter ablation should be the treatment of choice every time an AP is discovered. Cryoablation is recommended rather than RF ablation for APs that are very close to the AV node and present an increased risk for AV block during ablation, in particular septal APs, being safer, but having higher recurrence rate. The patient can resume competitive sports one month after the procedure according to American and European guidelines.

\section{Conflict of interest: none declared.}

\section{References}

I. Issa ZF, Miller JM, Zipes DP: Typical Atrioventricular Bypass Tracts. In Clinical Arrhythmology and Electrophysiology: A companion to Braunwald's Heart Disease: Third edition. Elsevier Inc, Philadelphia; 2018, 599-676.

2. Rao AL, Salerno JC, Asif IM, Drezner JA. Evaluation and Management of Wolff-Parkinson-White in Athletes. Sports Health. 2014; 6: 326-332.

3. Zipes DP, Link MS, Ackerman MJ, Kovacs RJ, Myerburg RJ, Estes NAM 3rd. Eligibility and Disqualification Recommendations for Competitive Athletes With Cardiovascular Abnormalities: Task Force 9: Arrhythmias and Conduction Defects: A Scientific Statement From the American Heart Association and American College of Cardiology. J Am Coll Cardiol. 2015; 66:24I2-2423

4. Corrado DI, Pelliccia A, Heidbuchel H, Sharma S, Link M, Basso C, Biffi A, Buja G, Delise P, Gussac I, Anastasakis A, Borjesson M, Bjørnstad HH, Carrè F, Deligiannis A, Dugmore D, Fagard R, Hoogsteen J, Mellwig KP, Panhuyzen-Goedkoop N, Solberg E, Vanhees L, Drezner J, Estes NA 3rd, lliceto S, Maron BJ, Peidro R, Schwartz PJ, Stein R, Thiene G, Zeppilli P, McKenna WJ. Recommendations for interpretation of I2-lead electrocardiogram in the athlete. Eur Heart J. 2010; 31:243-59.
5. Pelliccia AI, Fagard R, Bjørnstad HH, Anastassakis A, Arbustini E, Assanelli D, Biffi A, Borjesson M, Carrè F, Corrado D, Delise P, Dorwarth U, Hirth A, Heidbuchel H, Hoffmann E, Mellwig KP, Panhuyzen-Goedkoop N, Pisani A, Solberg EE, van-Buuren F, Vanhees L, Blomstrom-Lundqvist C, Deligiannis A, Dugmore D, Glikson M, Hoff PI, Hoffmann A, Hoffmann E, Horstkotte D, Nordrehaug JE, Oudhof J, McKenna WJ, Penco M, Priori S, Reybrouck T, Senden J, Spataro A, Thiene G. Recommendations for competitive sports participation in athletes with cardiovascular disease: a consensus document from the Study Group of Sports Cardiology of the Working Group of Myocardial and Pericardial Diseases of the European Society of Cardiology. Eur Heart J. 2005;26: 1422-45.

6. Pelliccia AI, Zipes DP, Maron BJ. Bethesda Conference \#36 and the European Society of Cardiology Consensus Recommendations Revisited A Comparison of U.S. and European Criteria for Eligibility and Disqualification of Competitive Athletes With Cardiovascular Abnormalities. J Am Coll Cardiol. 2008; 52:1990-6.

7. Page RL, Joglar JA, Caldwell MA, Calkins HI, Conti JBI, Deal BJI, Estes NA 3rdI, Field MEI, Goldberger ZDI, Hammill SCI, Indik $\mathrm{JHI}$, Lindsay BDI, Olshansky BI, Russo AMI, Shen WKI, Tracy CMI, Al-Khatib SM. 2015 ACC/AHA/HRS Guideline for the Management of Adult Patients With Supraventricular Tachycardia A Report of the American College of Cardiology/American Heart Association Task Force on Clinical Practice Guidelines and the Heart Rhythm Society. Circulation. 2016; 133:e506-e574.

8. Bastani HI, Insulander P, Schwieler J, Tabrizi F, Braunschweig F, Kennebäck G, Drca N, Jensen-Urstad M. Cryoablation of superoparaseptal and septal accessory pathways: a single centre experience. Europace. 2010; 12:972-7.

9. Neumann T. Cryoablation of 'delicate' accessory pathways. Europace. 2010; |2:921-2.

10. Liang M, Wang Z, Liang Y, Yang G, Jin Z, Sun M, Han Y. Different Approaches for Catheter Ablation of Para-Hisian Accessory Pathways Implications for Mapping and Ablation. Circ Arrhythm Electrophysiol. 2017; I0(6): 0004882

II. Karadeniz Cl, Akdeniz C, Turan O, Tuzcu V. Cryoablation of Septal Accessory Pathways in Children: Midterm Results. Pacing Clin Electrophysiol. 2014; 37:1095-9.

12. Kerr CR, Gallagher JJ, German LD. Changes in Ventriculoatrial Intervals with Bundle Branch Block Aberration During Reciprocating Tachycardia in Patients with Accessory Atrioventricular Pathways. Circulation. 1982; 66:196-201. 